\title{
Species Turnover across Different Life Stages from Seedlings to Canopy Trees in Swamp Forests of Central Brazil
}

\author{
Clarissa G. Fontes, ${ }^{1}$ Bruno M. T. Walter, ${ }^{2}$ José Roberto R. Pinto, ${ }^{3}$ and Gabriel Damasco ${ }^{1}$ \\ ${ }^{1}$ Department of Integrative Biology, University of California Berkeley, Berkeley, CA 94720-3140, USA \\ ${ }^{2}$ Embrapa Recursos Genéticos e Biotecnologia, Cenargen/Herbário, 70770-917 Brasília, DF, Brazil \\ ${ }^{3}$ Departamento de Engenharia Florestal, Universidade de Brasília, 70910-900 Brasília, DF, Brazil \\ Correspondence should be addressed to Clarissa G. Fontes; clafontes@berkeley.edu
}

Received 21 September 2015; Revised 10 November 2015; Accepted 10 November 2015

Academic Editor: Béla Tóthmérész

\begin{abstract}
Copyright ( 12015 Clarissa G. Fontes et al. This is an open access article distributed under the Creative Commons Attribution License, which permits unrestricted use, distribution, and reproduction in any medium, provided the original work is properly cited.
\end{abstract}

\begin{abstract}
Processes driving the assembly of swamp forest communities have been poorly explored. We analyzed natural regeneration and adult tree communities data of a swamp gallery forest in Central Brazil to discuss the role of ecological filters in shaping plant species turnover in a successional gradient. Species data of 120 plots were used to assess species turnover between natural regeneration and adult tree communities. Our analyses were based on 4995 individuals belonging to 72 species. Community patterns were discerned using ordination analyses. A clear floristic turnover among plant life stages was distinguished. Regeneration community of swamp forests was richer in species composition than the adult community. Tree species commonly found in nonflooded gallery forests were present in the regeneration plots but not in the adult community. Differences in the floristic composition of these two strata suggest that not all species in the seedling stage can stand permanent flooding conditions and only a few tolerant species survive to become adult trees. We propose that natural disturbances play an important role by altering limiting resources, allowing seeds of nonflooded forest species to germinate. This paper elucidates the turnover between plant life stages in swamp forests and suggests mechanisms that may shape these communities.
\end{abstract}

\section{Introduction}

Among different habitat types found in Central Brazil, swamp gallery forests locally known as matas paludosas, matas de galeria inundáveis, and matas de brejo, are very peculiar and occur in permanently flooded soils [1-5]. These environments are considered important to the speciation of tropical plant lineages and contributed to the diversity of species in the Cerrado biome [6,7]. In addition to the current and nonoptimistic deforestation scenario, the swamp forests have a fragmented and confined distribution, making plant populations more vulnerable to extinction [5, 8-10]. Moreover, due to a low number of studies in this habitat, little is known about the ecological processes underlying the diversity of tree communities in swamp forests.

Understanding the mechanisms that assemble plant communities in swamp forests is not a simple task for tropical ecologists. While neutral models of biodiversity have argued that dispersal is one of the main determinants of local diversity $[11,12]$, other models propose that ecological features narrow the range of species diversity in local communities [13, 14]. The regional species pool encompasses all sets of species occurring in a certain region which are capable of coexisting in a certain community [15]. Thus, dispersal limitation caused by geographic distances and/or insulation will be the first filter to build local communities [16]. Once seeds or vegetative propagules are successfully dispersed, environmental conditions (e.g., temperature, humidity, soil nutrients, and water availability) will impose a selective pressure in the germination of seeds and establishment of saplings. In this phase, plant species lacking relevant functional traits to tolerate stress conditions (found in swamp environments) will be eliminated from the local community. Finally, ecological interactions such as herbivory, fungal infestation, and intra/ interspecific competition will impose a biotic constraint to the species' establishment. 
In addition, there are natural processes, such as local disturbances, that influence the intensity of ecological filters [16]. Gap openings increase the space, radiation, temperature, and nutrient availability for colonizing species whereas they decrease the water availability and humidity [17]. Thus, local patchy disturbances promote environmental heterogeneity allowing coexistence of competing species by increasing niche dimensionality within local communities. Since swamp gallery forests seem to be very dynamic with high rates of mortality and recruitment due to tree fall events $[4,10,18]$, natural disturbances might play a central role in promoting species turnover in this habitat.

Furthermore, in order to bear anoxic conditions, plant species must have functional traits (morphological, anatomical, and physiological adaptations) that allow them to inhabit flooded environments, whereas flood-intolerant species are eliminated by environmental pressure $[7,19,20]$. Even though swamp gallery forests can be usually found near to nonflooding forests, they differ significantly in their flora [21]. Hence, flooding regime is an important predictor of floristic turnover among gallery forests [10]. Regarding this debate, we propose that dispersal, disturbance, and ecological "filters" act from the regional species pool to local community to maintain plant community assembly in swamp gallery forests. Although some floristic surveys have been done in swamp forests in Cerrado [1-5, 8, 22-25], data on floristic turnover between adult trees and regeneration communities is still missing. Furthermore, it is poorly known if flooding also acts as a strong abiotic filter on the assembly of natural regeneration community.

Here, we aim to describe and compare the natural regeneration (seedlings and saplings) with the adult tree communities of a swamp gallery forest located in Central Brazil and discuss the role of ecological filters driving floristic dissimilarities and species turnover in a successional gradient. If both communities (regeneration and adult) are floristically and structurally similar, the anoxic condition may act as an abiotic filter throughout all plant life stages, imposing a strong constraint on the diversity of both regeneration and adult tree communities. On the other hand, if adult and regeneration communities are floristically different, we propose that dispersal from nonflooded forests is frequent and flooding may not restrain the diversity of seedlings and saplings in swamp forests. Furthermore, natural disturbance may play an important role by altering limiting resources (e.g., humidity and light) and flooding acts as an abiotic filter mainly on the adult community.

\section{Methods}

2.1. Study Area. The study was conducted at Sucupira Farm (SF), located in Brasília, Federal District, Brazil $\left(15^{\circ} 52^{\prime}\right.$ to $15^{\circ} 56^{\prime} \mathrm{S}$ and $48^{\circ} 00^{\prime}$ to $48^{\circ} 02^{\prime} \mathrm{W}$ ) (Figure 1). The Farm is a property of the Brazilian Federal Government (Ministry of Agriculture, Livestock and Food Supply (MAPA)), which ceded to Embrapa (Brazilian Agricultural Research Corporation) the rights to use the land. The SF total area is approximately $1,173.118$ hectares [26].
The climate of the region was Aw according to Köppen classification (tropical rainy), the average annual precipitation was around $1492.6 \mathrm{~mm}$, and the altitude ranges from 1,050 to $1,250 \mathrm{~m}$. The soils, in which the Farm is located, consist of conglomerates, sandstones, siltstones, mudstones, and different types of quartzites and slates [26]. The vegetation at SF includes gallery forest (subtypes: flooded and nonflooded), cerrado sensu stricto (subtypes: dense, typical, grassland, and rocky), and footpath [27].

The SF has a large number of water springs, which are responsible for the formation of the Açudinho and the Riacho Fundo streams. The latter is one of the main tributaries of the Paranoá Lake located in Brasília [26]. The studied swamp gallery forest is located on the right bank of the Riacho Fundo stream, close by its junction with the Açudinho stream (Figure 1). The area where the plots are established is preserved and maintained by Embrapa [4].

2.2. Sampling Design. We analyzed trees in two life stage classes: adult (1) and natural regeneration (2) communities. Each class was divided into two categories-adult trees (1): "trees under establishment" and "established trees"; natural regeneration (2): "saplings" and "seedlings." To sample the adult vegetation, we measured a grid with 40 permanent plots of $20 \times 10 \mathrm{~m}$ established by Guarino and Walter [3]. All trees, including ferns and palms, with DBH (diameter at breast height) of at least $3 \mathrm{~cm}$ were sampled. Trees under establishment were those individuals with $3 \mathrm{~cm} \leq \mathrm{DBH}>5 \mathrm{~cm}$ and established trees were plants with $\mathrm{DBH} \geq 5 \mathrm{~cm}$. To sample the natural regeneration, within each plot $(20 \times 10 \mathrm{~m})$ a subplot of $5 \times 5 \mathrm{~m}$ was randomly selected and the regeneration sampled in these plots was called saplings. The inclusion criteria for this category were DGH (diameter at ground height) greater than $1 \mathrm{~cm}$ and DBH smaller than $3 \mathrm{~cm}$, an adaptation of the method suggested by Felfili et al. [28]. In the lower right corner of each subplot of $5 \times 5 \mathrm{~m}$ we allocated, systematically, a small plot of $2 \times 2 \mathrm{~m}$, in order to sample the category of seedlings. In this category, we measured all individuals with the minimum height of $10 \mathrm{~cm}$ and DGH maximum of $1 \mathrm{~cm}$; this method was also adapted from Felfili et al. [28]. The adjustment of the method for the regeneration of swamp forest was necessary after observing some situations that occur regularly in the field. Many large adult trees are found lying on the forest floor, fall apparently caused by rainfall and strong winds, leading to the breakdown of the main trunk of many juvenile trees (saplings). Therefore, there are cases where the plant height does not match the age or life stage in which the plant is. Thus, we decided to use the diameter $(1 \mathrm{~cm})$, instead of the height, to differentiate categories of saplings and seedlings.

2.3. Data Analysis. The taxonomic system used was the Angiosperm Phylogeny Group [29]. The scientific names were standardized according to the vascular flora of Cerrado biome [21] and to the List of Species of the Brazilian Flora (2013). The specimens collected in this study were deposited in the Cenargen Herbarium (CEN), where they were identified. 


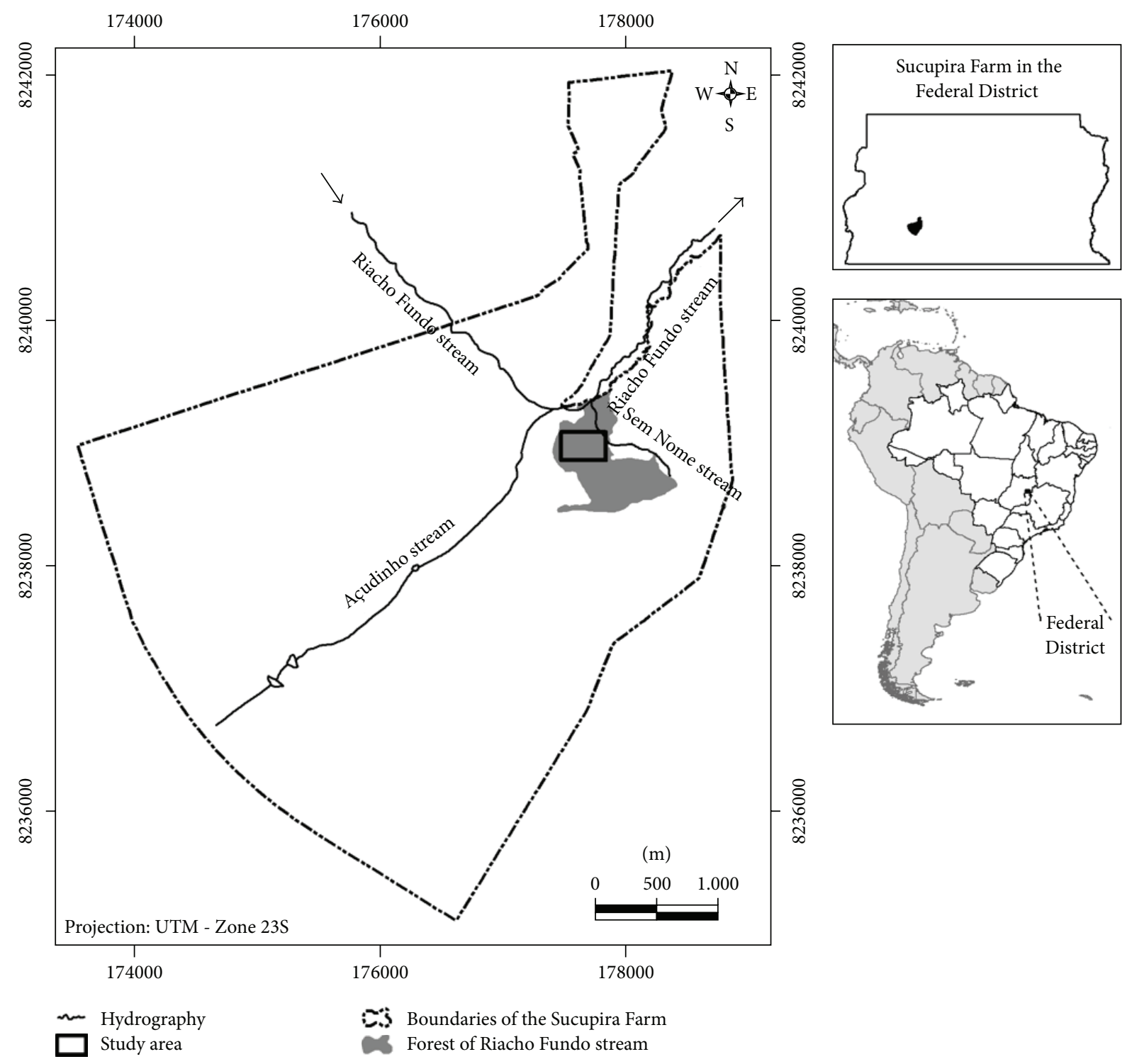

Figure 1: Location of the study area (Riacho Fundo forest) in Sucupira Farm, Federal District, Brazil.

To compare the structure and floristic composition between regeneration (seedlings and saplings) and adult trees (under establishment and established trees) communities we calculated the phytosociological parameters [30], the diversity indexes ( $H^{\prime}$ and $\left.J^{\prime}[31]\right)$, and the Nonmetric Multidimensional Scaling analysis (NMDS [32]). The NMDS ordination was based on quantitative data (species density) and the similarity index used was Bray-Curtis. For the NMDS analysis, the categories of established and under establishment trees were grouped in a single class of adult trees. The dead trees and the individuals of Protium spp. (in the seedling category) were excluded from the NMDS analysis, since they cannot be distinguished during the seedling stage (Protium spruceanum and Protium heptaphyllum). In addition, we analyzed the species score distribution of the NMDS to verify which species were responsible for the floristic similarity/dissimilarity between the categories.
The phytosociological parameters such as density, frequency, and dominance for the category of saplings and adult trees (under establishment + established trees) were calculated as suggested by Kent and Coker [30]. For seedlings, the dominance was not considered in the IV calculation because the diameter in this category is too small and negligible (the same is true for their basal area). The Importance Value (IV) was calculated for saplings and adult trees; for the category of seedlings we calculated the Occurrence Index (OCI $i=$ $\mathrm{RD} i+\mathrm{RF} i$, where $i$ represents the $i$ th species; RD is Relative Density; RF is Relative Frequency) in order to verify the most representative species of each stratum. Additionally, we calculated the Expanded Importance Value (EIV) for all the species [33]. This index, besides IV, takes into account the Sociological Position and the natural regeneration of the species, thus considering the vertical and horizontal structure of the forest [34]. To calculate the EIV, established and under 
establishment trees were grouped into a single life stage class (adult trees) and seedlings were excluded from the regeneration calculation.

\section{Results}

3.1. Floristic Composition. A total of 4995 individuals (considering the four categories) were recorded (205 dead), distributed in 39 botanical families, 58 genera, and 72 species (Appendix S1 in Supplementary Material available online at http://dx.doi.org/10.1155/2015/124851). A single species was identified only until family level and another individual were unable to be identified. In the category of seedlings, we sampled 795 individuals from 27 families, 41 genera, and 49 species (Appendix S1). One individual was dead. In the sapling category, 1472 trees were surveyed and they were distributed in 32 families, 45 genera, and 55 species. This includes 55 dead individuals. We computed 768 individuals in the category of trees under establishment (33 standing dead), belonging to 32 families, 41 genera, and 52 species. The category of established trees had 1960 individuals, of which 116 were dead. The living individuals were distributed in 30 families, 38 genera, and 45 species (Appendix S1).

Of the 72 species sampled, 26 occurred in all size categories. Five species were only found in the categories of adult trees (under establishment + established trees) and eight others were not present only in the established trees layer, having been observed in all other categories. The category of established trees had fewer numbers of exclusive species (only one), whereas in the categories of seedling and saplings the largest number of exclusive species was observed, each with five. Among the species that only occurred in the category of seedlings, we highlight the presence of Copaifera langsdorffii (Copaiba). This is the first record of this species naturally growing in a swamp gallery forest.

The families with greatest floristic richness were Melastomataceae (9 species), Rubiaceae (6), Myrtaceae (5), and Lauraceae (4). These families together represented $33.3 \%$ of the total species and $35.8 \%$ of all individuals sampled. The most important families (higher IV) varied in each size category (Appendix S2). While the Melastomataceae family had a high contribution to the community structure of all four categories, Clusiaceae was representative only in the established trees stratum. The family Myrtaceae had great importance in the regenerating categories (seedlings: 4th position, and saplings: 9th); however, its contribution decreased in the category of established (25th) and under establishment trees (13th). The species richness of this family remained constant in all four categories.

3.2. Vegetation Structure and Floristic Diversity. The total plant density was $67817.5 \mathrm{ind} \mathrm{ha}^{-1}$ (49 $687.5 \mathrm{ind} \mathrm{ha}^{-1}$ in the category of seedlings; 14720 ind ha $^{-1}$ in the category of saplings; and 960 and 2450 ind $^{-1}$ in the category of under establishment and established trees, resp.). The total basal area was $44 \mathrm{~m}^{2} \mathrm{ha}^{-1}, 9$ in the category of saplings, 1.2 for under establishment trees, and $33.8 \mathrm{~m}^{2} \mathrm{ha}^{-1}$ in the category

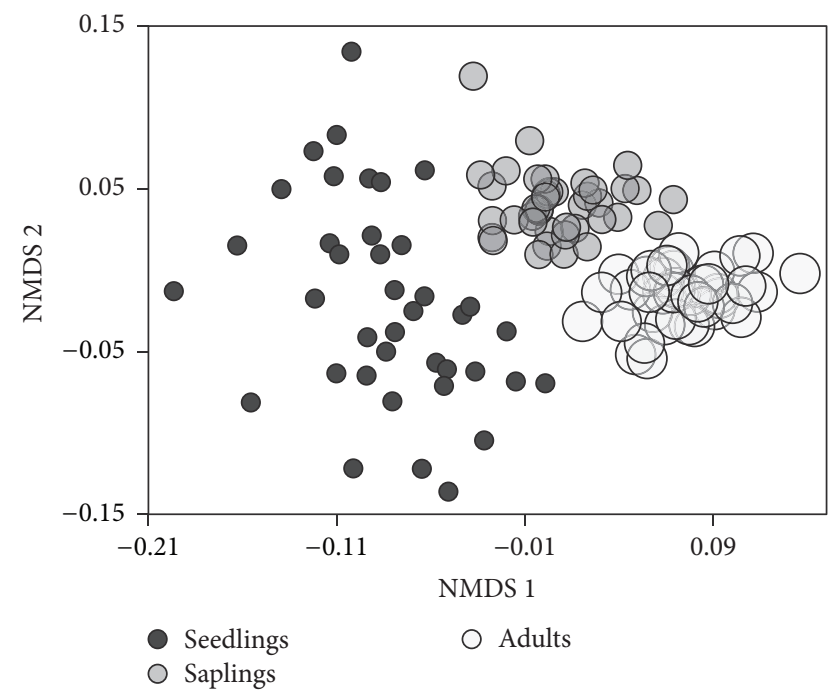

FIgURE 2: Nonmetric Multidimensional Scaling analysis (NMDS) ordination diagram of the 120 plots based on species abundance for seedlings (height $\geq 10 \mathrm{~cm}$ and $D G H \leq 1 \mathrm{~cm}$ ), saplings (DGH $>1 \mathrm{~cm}$ and $\mathrm{DBH}<3 \mathrm{~cm})$, and adult trees $(\mathrm{DBH} \geq 3 \mathrm{~cm})$ in Riacho Fundo swamp gallery forest, Central Brazil.

of established trees. The species with higher DBH were Magnolia ovata $(47.7 \mathrm{~cm})$, Virola urbaniana $(42.5 \mathrm{~cm})$, and Handroanthus umbellatus $(42 \mathrm{~cm})$.

The dead individuals accounted for 4.1\% (205 individuals) of the total number of plants sampled. The number of dead trees was higher in the category of established tree (116 individuals) and unrepresentative in the seedling category (1 individual). In the category of seedlings, the density of dead

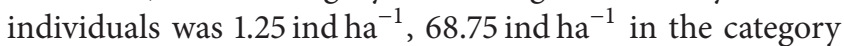
of saplings; 41.25 and $145 \mathrm{ind} \mathrm{ha}^{-1}$ in the strata of under establishment and established trees, respectively.

The category with the highest value of alpha diversity was the saplings $\left(H^{\prime}=3.18\right.$ and $\left.P=0.79\right)$, followed by trees under establishment $\left(H^{\prime}=3.16\right.$ and $\left.J=0.8\right)$, seedling $\left(H^{\prime}=3.05\right.$ and $\left.J=0.78\right)$, and established trees $\left(H^{\prime}=2.95\right.$ and $J=0.8)$. Although the values of $H^{\prime}$ and $J$ varied between the categories, the difference was small, suggesting that the diversity and distribution of species in the area were similar in the four categories.

3.3. Tree Community Gradient. The phytosociological and NMDS analysis indicated that the natural regeneration and the adult tree community are floristically and structurally different. The NMDS 1 mainly distinguished the seedlings from the categories of saplings and adult trees, while NMDS 2 detected the difference between saplings and adult trees (Figure 2). This result indicates that the saplings category is a transition between adult trees and seedlings; however, it tends to be, floristically and structurally, slightly more similar to adult trees than to seedlings. 
The analysis of the species score distributions (loadings) pointed out which species may be responsible for the observed floristic and structural gradient. Particular species were consistently important in the adult tree community, such as Miconia chartacea, Protium spruceanum, Richeria grandis, Xylopia emarginata, and Ferdinandusa speciosa, while others stood out in the seedlings category (e.g., Euterpe edulis, Maytenus sp., Eugenia florida, Virola urbaniana, Miconia nervosa, and Tapirira guianensis; Appendix S3-a). The species responsible for explaining the main differences between saplings and adult tree community along Axis 2 were Guarea macrophylla, Eugenia florida, Piper arboreum, Cybianthus glaber, Miconia nervosa, and Aniba heringeri (Appendix S3). However, it is important to notice that the seedling plots were largely distributed throughout Axis 2 in the NMDS analysis (Figure 2), and it could have influenced the species score distribution for Axis 2 (Appendix S3). Therefore, the importance of some species in the sapling category could have been under- or overestimated.

The most important species in the phytosociological analysis (IV, EIV, and OCI ranking) were, in general, similar to the ones found in the species score distribution analysis. Because we have joined at least two species (Protium heptaphyllum and Protium spruceanum), in the category of seedling, Protium spp. had the highest Occurrence Index (OCI), followed by Tapirira guianensis, Virola urbaniana, Miconia nervosa, and Euterpe edulis (Appendix S1). In the category of saplings, the species with higher IV was Guarea macrophylla, followed by Cyathea phalerata, M. nervosa, Miconia chartacea, and Xylopia emarginata. In the category of trees under establishment, the five species with higher IV were M. chartacea, G. macrophylla, X. emarginata, Ocotea aciphylla, and Miconia dodecan$d r a$. In the stratum of established trees, the species with higher IV was Ferdinandusa speciosa, followed by Richeria grandis, P. spruceanum, M. dodecandra, and M. chartacea (Appendix S1).

The species ranking, in the class of adult trees $(\mathrm{DBH} \geq$ $3 \mathrm{~cm}$ ), by values of IV and EIV, was similar to the exception of some species (Figure 3). For example, Guarea macrophylla was in 25th position in IV but rose to 10th in the ranking by EIV. This difference is due to the great importance of this species in the structure of natural regeneration (saplings). On the other hand, Nectandra cf. nitidula fell from 8th position in IV to 12th in EVI, since this species had low representation in the regenerating community.

Species that are important in the regeneration community, but are not very representative in the categories of adult trees, are Guarea macrophylla, Tapirira guianensis, Virola urbaniana, Euterpe edulis, and Miconia nervosa (shrub). The species Ferdinandusa speciosa and Richeria grandis, on the other hand, are important in the category of established trees, but their representativeness in the regeneration categories is small (Appendix S1). This difference suggests that (1) the forest structure and composition of the Riacho Fundo stream will change over the next few years or that (2) the flooding imposes a stronger constraint on higher vegetation strata, so anoxia-intolerant species will die before becoming an adult tree.

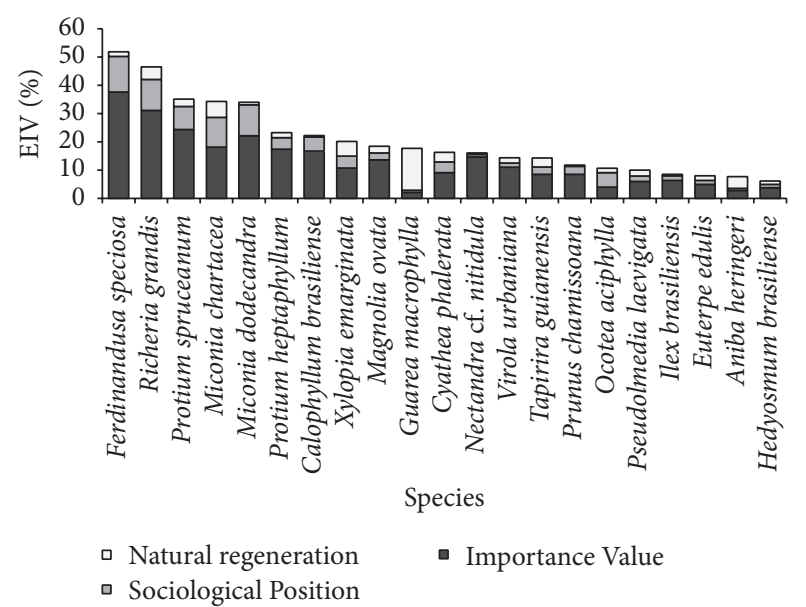

Figure 3: Expanded Importance Value (EIV) of the 21 most important species found in Riacho Fundo swamp gallery forest, Central Brazil. This index takes into account the Importance Value (IV), the Sociological Position (SP), and the natural regeneration (NR) of the species.

\section{Discussion}

There is a remarkable floristic turnover among plant life stages in swamp gallery forests. Seedlings and saplings are richer in species composition than adult communities. In addition, many tree species typically found in nonflooding gallery forests were sampled in the regeneration plots. This indicates that dispersal filter may be relaxed since gallery forests are arranged as ecological corridors amid savannas of Central Brazil [35]. Thus, propagules coming from other nonflooded communities can easily colonize swamp areas, especially those species with zoochorous dispersion [36]. A good example in the study area is Copaifera langsdorffi, more frequently found in nonflooded forests [21, 37], but present in the seedling category. However, once plants start to grow and become sapling, the floristic composition changes remarkably in the studied swamp forest. This shift in floristic composition suggests that soil waterlog may act as a strong abiotic filter in the assembly of juvenile and adult communities. Therefore, not all saplings and trees can stand permanent flooding conditions and only well-adapted species having anatomic, physiological, and biochemical traits could avoid or tolerate deleterious effects of low oxygen conditions and survive to become adult trees.

Moreover, classical studies suggest that floristic and structure differences among successional life stages can be explained by the Janzen-Connell theory [38-40]. According to this theory, seedlings that are farthest from the mother plant have a competitive advantage because they are less susceptible of being attacked by species-specific predators/pathogens, which are more commonly found around the adult tree $[41,42]$. The farther away from the conspecifics the seed or seedling is, the more likely the individual is to establish in the environment. The model hypothesizes that mortality near parents is virtually complete, recruitment is limited to areas at some distance from conspecifics, and adults are more evenly 
spaced than expected from the pattern of seed fall [38]. The open space in the vicinity of adults, then, is available for colonization by other species. Thus, the competitive exclusion is less likely and a large number of species can coexist in the community. Therefore, species might also have to overcome the biotic constraints imposed by herbivores and pathogens to be able to inhabit and survive at swamp environments.

Another aspect that should not be discarded, especially in regard to seedling density, is the phenology of species during the floristic survey. According to previous studies [43, 44], the absence of seedlings of a given species can be a consequence of the seed production periodicity, growth rates, and habitat conditions during the sampling period. For instance, Xylopia emarginata and Magnolia ovata occupied relevant positions of IV in the categories of adult trees and saplings, although they were not as representative in the seedling stage. The time of fruit ripening, which occurs in September for both species [45-47], coincided with our sampling period. Therefore, the period chosen for data collection may have had underestimated or overestimated the importance of some species at the seedling category [44].

The studied swamp forest, as verified by Fontes and Walter [4], is very dynamic with high rates of mortality and recruitment. Thus, natural disturbances such as gap openings are very frequent and the floristic dissimilarities among juveniles and adult tree communities are expected to be a result of the interaction between abiotic filters and natural disturbances. Therefore, local disturbances can act as an ecological filter by decreasing intra- and interspecific competition, or by temporarily changing the pressure of environmental conditions (e.g., light availability and humidity [16]). We believe that local disturbances may generate gradients of replacement among specialist and generalist species, according to the plant ability to deal with environmental changes [48]. Thus, it is expected that specialist species will benefit from a more homogeneous environment (in space and time), whereas ecological generalists should be favored in environments that are more heterogeneous [49-52].

In the study area, Ferdinandusa speciosa and Richeria grandis occupied the top IV positions in the adult category, but their importance in the regeneration stage was much lower. These species are frequently found in flooded forests while they are uncommon in well-drained environments [2, 3 , 53]. Unlike F. speciosa and R. grandis, Guarea macrophylla and Tapirira guianensis are generalist species in gallery forests, as they have the ability to inhabit flooded and nonflooded environments $[18,20,54,55]$. In the study area, $G$. macrophylla and T. guianensis were dominant in seedling and sapling categories, but they had low abundance in the adult community. This could be an example of replacement of specialist by generalist species at the studied swamp gallery forest. In addition, local disturbances may alter the intensity of ecological filters (e.g., flooding, light availability, and humidity) by changing microclimatic conditions. The opening of gaps increases the direct solar radiation in the understory and consequently the soil becomes drier [56]. These changes in the soil water saturation provide a favorable environment for the establishment of immigrant generalist species. In this sense, seedlings and saplings have not yet been imposed to flooding stresses and the regeneration community, therefore, is composed mainly of generalist species [57]. However, when saplings start growing and the gap is recovered, flooding might constrain the permanence of generalist species. As a result, flooding-intolerant species die before becoming an adult tree while most flooding-specialist saplings (e.g., Ferdinandusa speciosa and Richeria grandis) have advantage over generalists to compose the adult tree community.

\section{Conclusions}

This study advances our knowledge on the processes driving species diversity in swamp environments and it attempts to disentangle the drivers of species turnover across plant life stages. Our results elucidated that the relative importance of dispersal, environmental filters, and local disturbance in structuring plant communities of swamp forests might not be the same over different plant life stages. We suggest that both dispersal and disturbance strongly shape the regeneration communities, while the adult communities are mainly influenced by flooding conditions. However, future analysis based on long-term inventories, continuous environmental data, and biotic interactions should be performed in order to test the accuracy of our hypothesis. We expect that our findings encourage the investigation of ecological questions regarding the plant community assemblages of swamp habitats.

\section{Conflict of Interests}

The authors declare that there is no conflict of interests regarding the publication of this paper.

\section{Acknowledgments}

The authors thank João Benedito Pereira for his field work assistance, Carolyn B. Proença for her help in identifying the species of Myrtaceae, Alba Rezende for the useful insights, and Sérgio Noronha for the preparation of Figure 2 and Embrapa (Empresa Brasileira de Pesquisa Agropecuaria), UnB (Universidade de Brasilia), and CNPq (Pibic grant) for the financial and structural support.

\section{References}

[1] N. M. Ivanauskas, R. R. Rodrigues, and A. G. Nave, "Aspectos ecológicos de um trecho de floresta de brejo em Itatinga, SP: florística, fitossociologia e seletividade de espécies," Brazilian Journal of Botany, vol. 20, no. 2, pp. 139-153, 1997.

[2] M. F. Nogueira and I. Schiavini, "Composicao floristica e estrutura da comunidade arborea de uma mata de galeria inundavel em Uberlandia, MG., Brasil," Bioscience Journal, vol. 19, no. 2, 2006.

[3] E. D. S. G. Guarino and B. M. T. Walter, "Fitossociologia de dois trechos inundáveis de Matas de Galeria no Distrito Federal, Brasil," Acta Botanica Brasilica, vol. 19, no. 3, pp. 431-442, 2005.

[4] C. G. Fontes and B. M. Walter, "Dinâmica do componente arbóreo de uma mata de galeria inundável (Brasília, Distrito Federal) em um período de oito anos," Brazilian Journal of Botany, vol. 34, no. 2, pp. 145-158, 2011. 
[5] J. H. R. Magalhães and R. C. Maimoni-Rodella, "Floristic composition of a freshwater swamp forest remnant in southeastern Brazil," Check List, vol. 8, no. 4, pp. 832-838, 2012.

[6] W. J. Junk, "Wetlands of tropical South America," in Wetlands of the World: Inventory, Ecology and Management, vol. 1, pp. 679739, Springer, Berlin, Germany, 1993.

[7] C. T. V. Rocha, D. A. Carvalho, M. A. Fontes, A. T. Oliveira Filho, E. Van Den Berg, and J. J. Marques, "Comunidade arbórea de um continuum entre floresta paludosa e de encosta em Coqueiral, Minas Gerais, Brasil," Revista Brasileira de Botânica, vol. 28, no. 2, pp. 203-218, 2005.

[8] M. T. Z. Toniato, H. D. F. L. Filho, and R. R. Rodrigues, "Fitossociologia de um remanescente de floresta higrófila (mata de brejo) em Campinas, SP,' Brazilian Journal of Botany, vol. 21, no. 2, pp. 197-210, 1998.

[9] R. R. Rodrigues and H. D. F. Leitão Filho, Matas Ciliares: Conservação e Recuperação, EDUSP, São Paulo, Brazil, 2000.

[10] A. D. P. Teixeira, M. A. Assis, F. R. Siqueira, and J. C. Casagrande, "Tree species composition and environmental relationships in a Neotropical swamp forest in Southeastern Brazil," Wetlands Ecology and Management, vol. 16, no. 6, pp. 451-461, 2008.

[11] G. Bell, "The distribution of abundance in neutral communities," The American Naturalist, vol. 155, no. 5, pp. 606-617, 2000.

[12] S. P. Hubbell, The Unified Neutral Theory of Biodiversity and Biogeography (MPB-32), vol. 32, Princeton University Press, 2001.

[13] R. J. Hobbs and D. A. Norton, "Ecological filters, thresholds, and gradients in resistance to ecosystem reassembly", in Assembly Rules and Restoration Ecology, pp. 72-95, Island Press, Washington, DC, USA, 2004.

[14] S. Díaz, S. Lavorel, F. De Bello, F. Quétier, K. Grigulis, and T. M. Robson, "Incorporating plant functional diversity effects in ecosystem service assessments," Proceedings of the National Academy of Sciences of the United States of America, vol. 104, no. 52, pp. 20684-20689, 2007.

[15] M. Pärtel, M. Zobel, K. Zobel, and E. Van Der Maarel, “The species pool and its relation to species richness: evidence from Estonian plant communities," Oikos, vol. 75, no. 1, pp. 111-117, 1996.

[16] J. A. Myers and K. E. Harms, "Seed arrival, ecological filters, and plant species richness: a meta-analysis," Ecology Letters, vol. 12, no. 11, pp. 1250-1260, 2009.

[17] J. S. Denslow, "Tropical rainforest gaps and tree species diversity," Annual Review of Ecology and Systematics, vol. 18, pp. 431451, 1987.

[18] S. D. F. Lopes and I. Schiavini, "Dinâmica da comunidade arbórea de mata de galeria da Estação Ecológica do Panga, Minas Gerais, Brasil," Acta Botanica Brasilica, vol. 21, no. 2, pp. 249-261, 2007.

[19] P. C. Lobo and C. A. Joly, "Aspectos ecofisiológicos da vegetação de mata ciliar do sudeste do Brasil," in Matas Ciliares: Conservação e Recuperação, R. R. Rodrigues and H. F. Leitão-Filho, Eds., vol. 1, pp. 143-157, EDUSP/Editora da Universidade de São Paulo, São Paulo, Brazil, 2000.

[20] M. de Matos and J. M. Felfili, "Florística, fitossociologia e diversidade da vegetação arbórea nas matas de galeria do Parque Nacional de Sete Cidades (PNSC), Piauí, Brasil," Acta Botanica Brasilica, vol. 24, no. 2, pp. 483-496, 2010.

[21] R. C. Mendonça, J. Felfili, B. M. T. Walter, M. C. Silva-Júnior, A. V. Rezende, and T. S. Filgueiras, "Flora vascular do bioma cerrado," in Cerrado: Ecologia e Flora, pp. 1028-1059, Embrapa, Brasília, Brazil, 2008.
[22] M. Paschoal and O. Cavassan, "A flora arbórea da mata de brejo do ribeirão do Pelintra, Agudos, SP," Naturalia, vol. 24, no. 1, pp. 171-191, 1999.

[23] A. D. P. Teixeira and M. A. Assis, "Caracterização florística e fitossociológica do componente arbustivo-arbóreo de uma floresta paludosa no Município de Rio Claro (SP), Brasil," Brazilian Journal of Botany, vol. 28, no. 3, pp. 467-476, 2005.

[24] L. Dietzsch, A. V. Rezende, J. R. R. Pinto, and B. A. S. Pereira, "Caracterização da flora arbórea de dois fragmentos de mata de galeria do Parque Canjerana, DF," Cerne, vol. 12, no. 3, pp. 201210, 2006.

[25] A. C. da Silva, E. Van Den Berg, P. Higuchi, and A. T. de Oliveira, "Comparação florística de florestas inundáveis das regiões Sudeste e Sul do Brasil," Revista Brasileira de Botânica, vol. 30, no. 2, pp. 257-269, 2007.

[26] B. M. T. Walter and A. B. Sampaio, A Vegetação da Fazenda Sucupira, Embrapa Recursos Genéticos e Biotecnologia, Brasília, Brazil, 1998.

[27] J. F. Ribeiro and B. M. T. Walter, "As principais fitofisionomias do bioma Cerrado," in Cerrado: Ecologia e Flora, vol. 1, pp. 152-212, Embrapa Cerrados/Embrapa Informação Tecnológica, Brasilia, Brazil, 2008.

[28] J. M. Felfili, F. A. Carvalho, and R. F. Haidar, Manual para o monitoramento de parcelas permanentes nos biomas Cerrado e Pantanal, Universidade de Brasília, Departamento de Engenharia Florestal, 2005.

[29] The Angiosperm Phylogeny Group, "An update of the Angiosperm Phylogeny Group classification for the orders and families of flowering plants: APG III," Botanical Journal of the Linnean Society, vol. 161, no. 2, pp. 105-121, 2009.

[30] M. Kent and P. Coker, Vegetation Description Andanalysis. A Practical Approach, John Wiley \& Sons, Chichester, UK, 1992.

[31] A. E. Magurran and A. Higham, "Information transfer across fish shoals under predator threat," Ethology, vol. 78, no. 2, pp. 153-158, 1988.

[32] B. McCune, J. B. Grace, and D. L. Urban, Analysis of Ecological Communities, vol. 28, MjM Software Design, Gleneden Beach, Ore, USA, 2002.

[33] W. K. D. Freitas and L. M. S. Magalhães, "Métodos e Parâmetros para Estudo da Vegetação com Ênfase no Estrato Arbóreo," Floresta e Ambiente, vol. 19, no. 4, pp. 520-540, 2012.

[34] J. R. S. Scolforo and A. Figueiredo Filho, Biometria Florestal: medição e volumetria de árvores, UFLA/FAEPE, Lavras, Brazil, 1998.

[35] J. F. Ribeiro, C. E. L. da Fonseca, and J. C. S. Silva, Cerrado: Caracterização e Recuperação de Matas de Galeria, Embrapa Cerrados, Planaltina, Brazil, 2001.

[36] F. Pinheiro and J. Ribeiro, "Síndromes de dispersão em matas de galeria do Distrito Federal," in Cerrado: Caracterização e Recuperação de Matas de Galeria, pp. 315-328, Embrapa Cerrados, Planaltina, Brazil, 2001.

[37] J. C. F. Resende, C. A. Klink, and I. Schiavini, "Spatial heterogeneity and its influence on Copaifera langsdorffii Desf. (Caesalpiniaceae)," Brazilian Archives of Biology and Technology, vol. 46, no. 3, pp. 405-414, 2003.

[38] E. W. Schupp, “The Janzen-Connell model for tropical tree diversity: population implications and the importance of spatial scale," The American Naturalist, vol. 140, no. 3, pp. 526-530, 1992.

[39] J. S. Petermann, A. J. F. Fergus, L. A. Turnbull, and B. Schmid, "Janzen-Connell effects are widespread and strong enough to 
maintain diversity in grasslands," Ecology, vol. 89, no. 9, pp. 2399-2406, 2008.

[40] R. Bagchi, T. Swinfield, R. E. Gallery et al., “Testing the JanzenConnell mechanism: pathogens cause overcompensating density dependence in a tropical tree," Ecology Letters, vol. 13, no. 10, pp. 1262-1269, 2010.

[41] D. H. Janzen, "Herbivores and the number of tree species in tropical forest," The American Naturalist, vol. 104, no. 940, pp. 501-528, 1970.

[42] J. H. Connell, "On the role of natural enemies in preventing competitive exclusion in some marine animals and in rain forest trees," in Dynamics of Populations, pp. 298-312, PUDOC, Wageningen, The Netherlands, 1971.

[43] J. M. Felfili, "Dynamics of the natural regeneration in the Gama gallery forest in central Brazil," Forest Ecology and Management, vol. 91, no. 2-3, pp. 235-245, 1997.

[44] I. Schiavini, J. C. F. Resende, F. D. G. Aquino, J. F. Ribeiro, and C. E. L. Fonseca, "Dinâmica de populações de espécies arbóreas em mata de galeria e mata mesófila na margem do Ribeirão Panga, MG," in Cerrado: Caracterização e Recuperação de Matas de Galeria, J. F. Ribeiro, C. E. L. Fonseca, and J. C. Sousa-Silva, Eds., pp. 267-299, Embrapa-CPAC, Brasília, Brazil, 2001.

[45] H. Lorenzi, Árvores Brasileiras: Manual de Identificação e Cultivo de Plantas Arbóreas Nativas do Brasil, vol. 4, Editora Plantarum, Nova Odessa, Brazil, 1992.

[46] E. Cazetta, P. Rubim, V. de Oliveira Lunardi, M. R. Francisco, and M. Galetti, "Frugivoria e dispersão de sementes de Talauma ovata (Magnoliaceae) no sudeste brasileiro," Ararajuba, vol. 10, no. 2, pp. 199-206, 2002.

[47] M. C. Silva-Júnior and B. A. S. Pereira, +100 Arvores do CerradoMatas de Galeria: Guia de Campo, Rede Sementes do Cerrado, Brasilia, Brazil, 2009.

[48] J. H. Connell and R. O. Slatyer, "Mechanisms of succession in natural communities and their role in community stability and organization," The American Naturalist, vol. 111, no. 982, pp. 1119-1144, 1977.

[49] D. J. Futuyma and G. Moreno, "The evolution of ecological specialization," Annual Review of Ecology and Systematics, vol. 19, pp. 207-233, 1988.

[50] M. Marvier, P. Kareiva, and M. G. Neubert, "Habitat destruction, fragmentation, and disturbance promote invasion by habitat generalists in a multispecies metapopulation," Risk Analysis, vol. 24, no. 4, pp. 869-878, 2004.

[51] V. Devictor, R. Julliard, and F. Jiguet, "Distribution of specialist and generalist species along spatial gradients of habitat disturbance and fragmentation," Oikos, vol. 117, no. 4, pp. 507-514, 2008.

[52] R. Kassen, "The experimental evolution of specialists, generalists, and the maintenance of diversity," Journal of Evolutionary Biology, vol. 15, no. 2, pp. 173-190, 2002.

[53] A. B. Sampaio, B. M. T. Walter, and J. M. Felfili, "Diversidade e distribuição de espécies arbóreas em duas matas de galeria na micro-bacia do Riacho Fundo, Distrito Federal," Acta Botanica Brasilica, vol. 14, no. 2, pp. 197-214, 2000.

[54] M. C. da Silva Jr., J. M. Felfili, P. E. Nogueira, and A. V. Rezende, Análise Florística das Matas de Galeria no Distrito Federal, Matas de Galeria, Cerrado, South America, 1998.

[55] E. Lenza and P. E. Oliveira, "Biologia reprodutiva de Tapirira guianensis Aubl. (Anacardiaceae), uma espécie dióica em mata de galeria do Triângulo Mineiro, Brasil," Revista Brasileira de Botânica, vol. 28, no. 1, pp. 179-190, 2005.
[56] C. Uhl, K. Clark, N. Dezzeo, and P. Maquirino, "Vegetation dynamics in Amazonian treefall gaps," Ecology, vol. 69, no. 3, pp. 751-763, 1988.

[57] F. Jabot, R. S. Etienne, and J. Chave, "Reconciling neutral community models and environmental filtering: theory and an empirical test," Oikos, vol. 117, no. 9, pp. 1308-1320, 2008. 

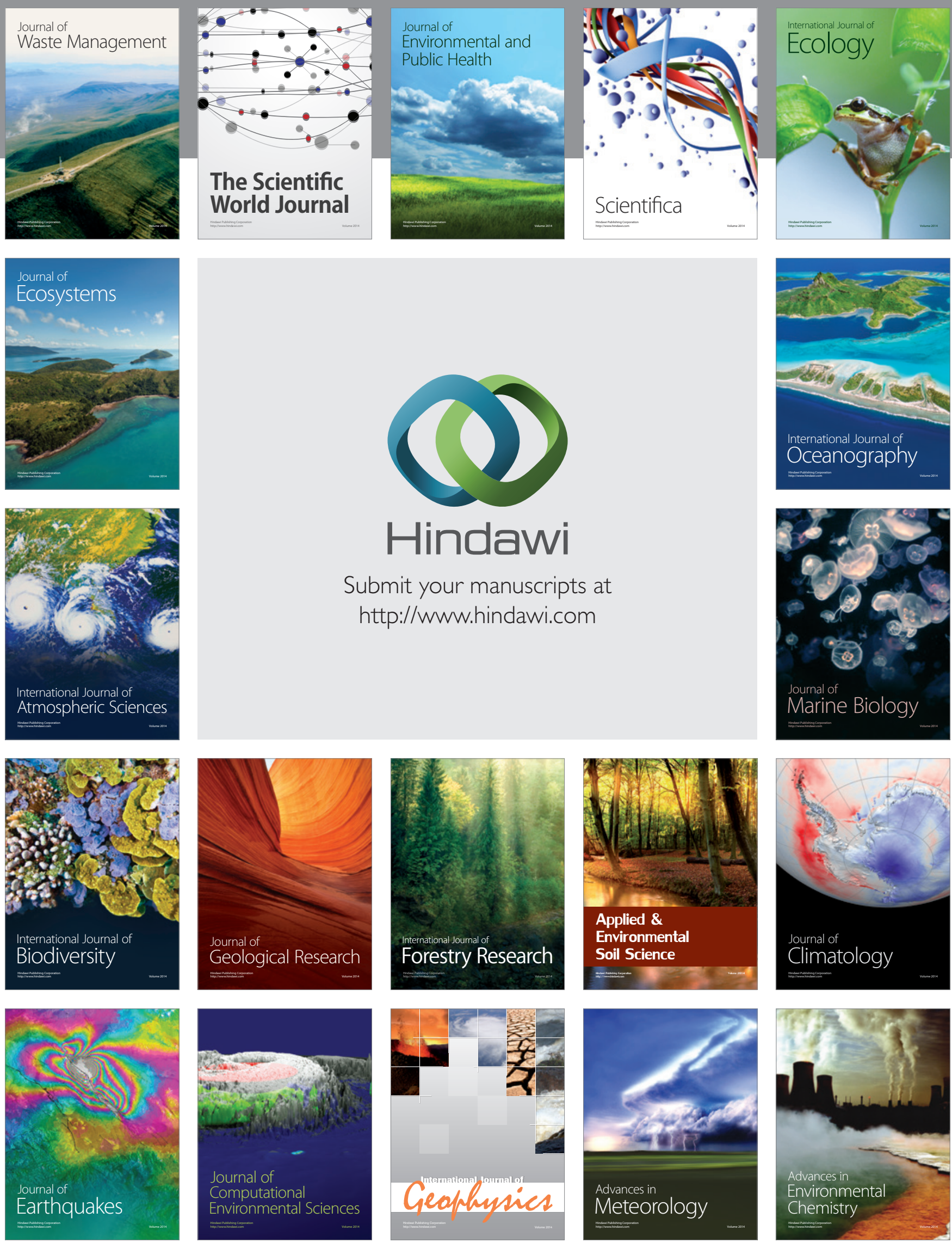